\title{
How to Create Value(s) in the Sharing Economy: Business Models, Scalability, and Sustainability
}

\author{
Aurélien Acquier, Valentina Carbone, and David Massé
}

\author{
"Sharing economy is a catch-all that includes ambitious" \\ young Internet startups, companies that are worth \\ millions on the stock market, and neo-hippies with \\ political and social objectives.
}

\author{
Cerise Sudry-le-Dû \\ Journalist
}

In Les Inrockuptibles (2015)

\begin{abstract}
By organizing peer-to-peer exchanges and promoting access over ownership, the sharing economy is transforming a great variety of sectors. Enjoying fast growth, the sharing economy is an umbrella term encompassing heterogeneous initiatives that create different types of economic, environmental, or social value. This heterogeneity triggers tensions and intense disputes about the perimeter of the field. Do Airbnb and Uber belong to the sharing economy? How do we consider practices such as gifting, renting, and swapping that existed before the sharing economy boom? To sort out this complexity, we have adopted a pragmatic and grounded approach examining 27 initiatives that claim to be part of, or are perceived as emblematic of the sharing economy. We develop a typology of sharing economy business models revealing four configurations: shared infrastructure providers, commoners, missiondriven platforms, and matchmakers. Each configuration exhibits specific value-creation logics, scalability issues, sustainability impacts, and potential controversies. Our results provide guidance for sharing entrepreneurs, for established businesses that want to embrace the principles of the sharing economy, and for public actors wishing to regulate or support the field.
\end{abstract}

\section{Introduction}

A central idea of the sharing economy is the optimization of under-used assets (e.g., physical assets such as cars, apartments, individual devices, and money or intangible assets such as skills and knowledge) by pooling or sharing them through digital platforms (Benkler, 2004). From this initial idea, the sharing economy emerged as a popular label to refer to different initiatives that either connect individuals through platforms to carry out sales, rentals, swaps, or donations (Gansky, 2012) or set up more centralized "product-service systems" to provide access instead of use, thus intensifying the use of idle assets (Botsman \& Rogers, 2010).

Sharing practices such as gifting, renting, swapping, or bartering have existed for ages. They traditionally took place at the individual or community level and in the domestic sphere, outside the market logic, with a strong sense of informality and social reciprocity. Over the last decade, these formerly domestic and local practices have been "dramatically scaled by the capitalist engine of technology-powered markets" to give rise to "stranger-sharing" in global markets (Sundararajan, 2016). According to PwC, the sharing economy was estimated at $\$ 15$ billion USD in revenue worldwide in 2015 , with the potential to reach $\$ 335$ billion USD by 2025 (PWC, 2015). As of 2016, 72\% of Americans had used some type of sharing platform or space (Smith, 2016).

As the rapid success of platforms such as Kickstarter, Coursera, Uber, and Airbnb illustrate, the development of the sharing economy reshapes a large number of economic sectors (e.g., finance, education, mobility, hospitality), simultaneously offering real entrepreneurial opportunities and constituting a threat of disruption for traditional sectors (Fréry et al., 2015; Guttentag, 2015). 


\section{How to Create Value(s) in the Sharing Economy: Business Models, Scalability, and Sustainability Aurélien Acquier, Valentina Carbone, and David Massé}

SNCF, the national railway company in France, estimated that the rise of BlaBlaCar, a European-based shared mobility platform created in 2006, had already caused a more than $10 \%$ decrease in their business. Subsequently, SNCF invested $€ 28$ million ( $\sim 42$ million $\mathrm{CAD}$ ) in June 2015 to acquire Ouicar, a peer-to-peer car rental platform.

The sharing economy is fascinating and complex because it combines ingredients from both market and non-market logics, along with inspirations from a variety of cognitive and normative frames, encapsulated in very different types of organizations (Acquier, Carbone, \& Massé, 2017). By combining environmental concerns for resource optimization, a social orientation towards communities and social exchange, and pointing to market opportunities, the sharing economy holds great promise in terms of sustainability or shared-value creation, "which involves creating economic value in a way that also creates value for society by addressing its needs and challenges" (Porter \& Kramer, 2011). The hybrid nature of the sharing economy generates definitional disputes in the academic world (see Table 1), and triggers controversial debates among experts, such as the one concerning the logic driving sharing economy entrepreneurs: a pure forprofit logic versus the pursuit of social and environmental goals. Indeed, the sharing economy is riddled with tensions and paradoxes (Acquier, Daudigeos, \& Pinkse, 2017), thereby creating a lot of complexity and confusion for entrepreneurs, established companies, and public regulators and making it hard to understand the underlying mechanisms of value creation, value distribution, and societal impacts of the sharing economy.

In this article, we propose to sort out the complexity of the sharing economy field by developing a typology of sharing economy business models. By distinguishing value-creation and value-distribution mechanisms, we reveal four configurations of sharing economy organizations: shared infrastructure providers, commoners, mission-driven platforms, and matchmakers. Each configuration rests on specific value-creation logics and exhibits scalability issues, specific sustainability impacts, and potential controversies. Beyond providing guidance for sharing economy entrepreneurs, our model has also significant implications for established businesses seeking to grasp business opportunities in the sharing economy, as well as for public actors who wish to regulate or support the field.

\section{Definitional Disputes Around the Sharing Economy}

There are currently many different definitions of the sharing economy, and agreeing on a shared definition is a conceptual challenge for several reasons. Because of its normative dimension, the sharing economy can be analyzed as an "essentially contested concept" that "inevitably involve[s] endless disputes about [its] proper uses on the part of its users" (Gallie, 1955). Indeed, the field is riddled with normative, empirical, and conceptual contestations about its scope and impacts.

First, many disputes are related to the environmental and social impacts of the sharing economy. Its advocates have praised the sharing economy for being a sustainable alternative to the currently unsustainable economy (Chase, 2015; Voytenko Palgan et al., 2017) by creating social bonding (John, 2013; McLaren \& Agyeman, 2015), fighting against planned obsolescence (Demailly \& Novel, 2014), favouring a better usage of resources and assets (Heinrichs, 2013), standing against the power of monopolistic firms (Kostakis \& Bauwens, 2014), and creating initiatives to move towards more “conscious capitalism" (O'Toole \& Vogel, 2011). On the other hand, opponents denounce the sharing economy as a form of "pseudo-sharing, [...] whereby commodity exchange and potential exploitation of consumer cocreators present themselves in the guise of sharing" (Belk, 2014). In this perspective, the "feel-good" sharing rhetoric constitutes a form of mystification that tends to hide the true impacts of the sharing economy. Studies have shown that the environmental benefits of the sharing economy may be overstated, as economic motivations generally prevail over environmental concerns in user motivations (Barnes \& Mattsson, 2016; Böcker \& Meelen, 2017). Most critics also point to the social costs of sharing economy platforms, denouncing what they perceive as a parasitical development logic that rests on irresponsible business models of platforms, which extend harsh free-market practices into previously protected areas of our lives (Slee, 2015). From this perspective, the sharing economy is thought to conceal a neoliberal agenda creating unregulated marketplaces, unprotected labour markets based on new forms of digital slavery, unfair competition, tax avoidance, and a transfer of risks to individual users (Martin, 2016).

Second, the conceptual boundaries are unclear between the sharing economy and other neighbouring concepts such as collaborative consumption, the peer- 


\section{How to Create Value(s) in the Sharing Economy: Business Models, Scalability, and Sustainability Aurélien Acquier, Valentina Carbone, and David Massé}

to-peer economy, crowd-based/platform capitalism, on-demand/gig economy, economy of access, or the circular economy. Though these concepts partly overlap, they are not completely synonymous and seem to be largely shaped by each author's ideological or academic ends (Murillo et al., 2017).

Definitions of the sharing economy concept itself vary greatly among authors and seem difficult to reconcile. Broadly speaking, there are two types of definitions of the sharing economy: narrow and broad definitions (see Table 1 for illustrations). Researchers who adopt narrow definitions tend to start from a normative characterization of sharing in order to frame the sharing economy as a more specific, restricted, and workable empirical object. While this strategy may be more rigorous from an analytical and academic point of view, it may simply bypass the complexity of the sharing economy as a field of practices. Moreover, the criteria used to define the sharing economy may be specific to each author, resulting in an assortment of individually coherent, but inconsistent definitions at the field level. For example, some observers argue that Uber should not be considered as part of the sharing economy, either because it focuses solely on value capture (Godelnik, 2014) or because, instead of car-sharing, it offers a permanent professional taxi service (Frenken \& Schor, 2017; Meelen \& Frenken, 2015). At the same time, many critics seem to equate the sharing economy with "Uberlike" initiatives (peer-to-peer and profit-driven platforms) and disregard other forms of initiatives that explore different logics of value creation (founded on peer-to-peer "commoning" or non-profit objectives) (Slee, 2015). Keeping in mind the "essentially contested" nature of the sharing economy concept, this may lead to endless academic and normative debates about what the sharing economy is, is not, or should be.

Other studies tend to define the field more broadly, including both peer-to-peer and business-to-peers initiatives, covering both market and non-market mechanisms (Schor, 2014). These approaches tend to be more focused on how actors make sense of the field, exploring its complexity, tensions, and hybridity. We adopt this perspective and define the sharing economy as a set of initiatives that increase the availability and efficiency of sub-utilized resources in society by organizing peer-to-peer exchanges or promoting access over ownership, or both. This broad and comprehensive definition is coherent with our objective to make sense of the complexity of the field by analyzing the different value-creation mechanisms in the field. It is coherent with other definitions, for example, that of Munoz and
Cohen, who define the sharing economy as "a socioeconomic system enabling an intermediated set of exchanges of goods and services between individuals and organizations which aim to increase efficiency and optimization of sub-utilized resources in society" (Muñoz \& Cohen, 2017).

\section{Methodology}

This paper is based on a two-year project (between 2014 and 2016) aimed at assessing the environmental and social impacts of sharing economy initiatives in France and other countries in Europe (Acquier et al., 2016). The empirical research was focused on material goods, exploring how production, gifting, resale, lending, and repair are being transformed by the rise of online exchange platforms and "third places" (mainly hackerspaces and fab labs). To overcome the definitional disputes around the sharing economy, we have adopted a pragmatic and grounded approach. We start from initiatives that claim to be part of the sharing economy or that are commonly perceived as very emblematic of this economy. The bulk of our empirical material is made up of 30 semi-structured interviews with the founders of 27 collaborative projects - mainly in France - covering a variety of practices (gifting, rental, lending, production, repair, and resale) and diverse industries (see Appendix 1). The questions were structured around four main topics: the background and motivation for creating the project, the social and environmental promises and impacts, the choice of business model, and the initiative's growth potential and issues. In addition, we interviewed 11 managers from established companies to understand how they engage in the sharing economy. We also collected secondary data to provide further examples and illustrations supporting our arguments.

\section{A Business Model Approach}

Although it was originally developed and formalized in the context of for-profit companies (Zott \& Amit, 2010), the business model concept has also been applied to a variety of governance models and limited-profit initiatives such as social innovation (Yunus et al., 2010) to understand how the organization interacts with a broader ecosystem (Lepak et al., 2007), and how it responds to sustainability issues (Boons \& Lüdeke-Freund, 2013) or to growing expectations in terms of taking responsibility for handling its products at the end-of-life stage (Kortmann \& Piller, 2016). Research on business models mainly focuses on: 1) how initiatives create value for clients and 2) how the value created is captured by the 


\section{How to Create Value(s) in the Sharing Economy: Business Models, Scalability, and Sustainability Aurélien Acquier, Valentina Carbone, and David Massé}

Table 1. Examples of narrow vs. broad definitions of the sharing economy (continued on next page)

\section{Examples of \\ Narrow Definitions}

Benkler (2004)

\section{Definition}

Refers to "sharing goods" as "a class of resources or goods that are amenable to being shared within social sharing systems rather than allocated through markets" (p. 356)

Social sharing also constitutes an "alternative modality of production" (p. 330) based on gifting and free participation among "weakly connected participants" (p. 332-334)

\section{Key Hypotheses}

- Social sharing constitutes a distinct mode of transaction (distinct from market price mechanism) and a distinct mode of production (different from market, hierarchies, and state mechanisms)

- Excludes secondary markets from social sharing

- As a mode of production, social sharing involves a logic of gifting by contributors
Belk (2014)
Distinguishes "true" vs. "pseudo-sharing"

"Sharing is an alternative to the private ownership that is emphasized in both marketplace exchange and gift-giving" (p. 10)

Pseudo-sharing is a "phenomenon whereby commodity exchange and potential exploitation of consumer co-creators present themselves in the guise of sharing" (p. 7) or "business relationship masquerading as communal sharing" (p. 11)
- “True sharing” excludes commercial exchange, reciprocation, and self-interest or transfer of individual property

- Gifting is not sharing

- Sharing implies a sense of collective property/belonging
Cockayne (2016)

"The on-demand or 'sharing' economy is a term that describes digital platforms that connect consumers to a service or commodity through the use of a mobile application or website" (p. 73)
- Restricts the sharing economy field to peer-to-peer, digital, profit-driven platforms
Eckhardt \& Bardhi (2016)

"The access economy, [...] also known as the sharing, or peer-to-peer, economy, [...] provides temporary access to consumption resources for a fee or for free without a transfer of ownership" (p. 210)
- Access (vs. ownership)

- Excludes gift giving or bartering

- Sharing and access take on different meanings in market vs. non-market economies
Frenken \& Schor (2017)

\section{Define the sharing economy as "consumers} granting each other temporary access to underutilized physical assets ('idle capacity'), possibly for money" (p. 2-3)
- Excludes centralized systems

- Excludes reselling platforms

- Excludes the provision of on-demand services

- Excludes production (focuses on consumption)
Stephany (2015)
"The sharing economy is the value in taking underutilized assets and making them accessible online to a community, leading to a reduced need for ownership of those assets" (p. 9)
- Focuses on for-profit initiatives that promote access instead of ownership

- Beyond peer-to-peer platforms, the sharing economy includes business-toconsumer (B2C) companies such as Zipcar and Rent the Runway that rent directly to consumers 


\section{How to Create Value(s) in the Sharing Economy: Business Models, Scalability, and Sustainability Aurélien Acquier, Valentina Carbone, and David Massé}

Table 1. (continued) Examples of narrow vs. broad definitions of the sharing economy

\begin{tabular}{ll}
$\begin{array}{l}\text { Examples of } \\
\text { Broad Definitions }\end{array}$ & Definition \\
\hline Habibi et al. (2017) & $\begin{array}{l}\text { "[We] suggest a sharing-exchange continuum that } \\
\text { helps distinguish the degree to which actual } \\
\text { sharing is being offered" (p. 115) }\end{array}$ \\
\hline Lessig (2008) & $\begin{array}{l}\text { Defines the hybrid economy as "either a } \\
\text { commercial entity that aims to leverage value } \\
\text { from a sharing economy, or it is a sharing } \\
\text { economy that builds upon a commercial entity to } \\
\text { better support its sharing aims" (p. 177) }\end{array}$
\end{tabular}

Key Hypotheses

- The sharing economy is a diverse field with hybrid forms that fall along a continuum between "true" and "pseudosharing"

$\begin{array}{ll}\text { Munoz \& Cohen (2017) } & \text { “A socio-economic system enabling an } \\ & \text { intermediated set of exchanges of goods and } \\ & \text { services between individuals and organizations } \\ & \text { which aim to increase efficiency and optimization } \\ \text { of sub-utilized resources in society" }\end{array}$

- Most initiatives exhibit for-profit and nonprofit dimensions simultaneously

"Sharing economy activities fall into four broad
categories: recirculation of goods, increased
utilization of durable assets, exchange of services,
and sharing of productive assets" (p. 2)

- Includes both business-to-business, business-to-customers, for-profit and non-profit initiatives, reselling, gifting
Botsman (2013)

\author{
"An economic model based on sharing \\ underutilized assets from spaces to skills to stuff \\ for monetary or non-monetary benefits"
}

- Includes both business-to-business, business-to-customers, for-profit and non-profit initiatives, reselling, gifting
- Includes both business-to-business,
business-to-customers, for-profit and
non-profit initiatives, reselling, gifting organization or distributed in the initiative's ecosystem (Bowman \& Ambrosini, 2000). Examining these two questions, we reveal two central tensions in the sharing economy field, as described in the sub-sections that follow.

\section{Value-creation mechanisms: From peer-to-peer} intermediation to centralized resource pooling Overall, the sharing economy creates value by providing access and intensifying the use of under-utilized assets. It does so through two principal value-creation mechanisms:

1. Peer-to-peer intermediation: some initiatives create value by organizing decentralized peer-to-peer transactions. Typically, these are sharing economy platforms (such as Airbnb) that connect peers through distributed, large-scale digital networks in order to organize decentralized production, distribution, and exchange of products and services.
2. Centralized resource pooling: some initiatives create value by creating and providing access to a centralized resource pool. This typically corresponds to "access-driven business models" or "product-service systems" where for-profit companies (such as ZipCar) create a centralized infrastructure that is accessible for short-term rental. This also corresponds to initiatives such as Wikipedia, where individual decentralized contributions are stored and aggregated in a central pool (the Wikipedia website) that is made freely available to users.

These two modes of value creation are not necessarily exclusive, and a hybrid mode may be formed by combining them. For example, collaborative production initiatives intend primarily to give access to production resources by pooling data and material assets (premises, machines, expertise, etc.). Additionally, many such initiatives build decentralized networks of peers to facilitate learning and exchange through personal interactions 


\section{How to Create Value(s) in the Sharing Economy: Business Models, Scalability, and Sustainability Aurélien Acquier, Valentina Carbone, and David Massé}

(Kohtala \& Bosqué, 2014). These two value-creation mechanisms can therefore be viewed as two shaping forces of the sharing economy, emphasizing either peer-to-peer decentralization or resource pooling.

\section{Value capture and distribution mechanisms}

Most scholars studying sharing economy as a field of practices observe that "the sharing economy spans the continuum between market economies and gift economies." (Mair \& Reischauer, 2017; Schor, 2014; Sundararajan, 2016). Accordingly, we distinguish two mechanisms for capturing and distributing value in the sharing economy:

\section{Dominant focus on economic value creation and cap-} ture: this refers to a series of for-profit initiatives endorsing shareholder value maximization, adopting a market logic and monetizing their services (Teece, 2010). This typically corresponds to initiatives that are discussed under the label "platform capitalism" (Kenney \& Zysman, 2016; Morozov, 2014): access business-models driven by market logics (Bardhi \& Eckhardt, 2012).

\section{Dominant focus on extended/shared value creation} and distribution: in contrast, other initiatives are set up as non-profit or limited-profit initiatives, where economic sustainability is a means to promote a social or environmental mission (Seelos \& Mair, 2007; Yunus et al., 2010). These initiatives may be entirely non-profit (such as Wikipedia) or hybrid projects using market mechanisms to promote their social mission. As a result, while they may develop for-profit activities and capture part of the value created, they do so with the publicly-stated aim of sharing this value within their ecosystem according to their mission and governance.

Once again, the differentiation between these mechanisms should be viewed as a continuum rather than a strict cleavage, and they are likely to evolve according to the life of each project (Schor et al., 2015).

\section{Four Business Model Configurations in the Sharing Economy}

By plotting a matrix with these two dimensions, we derive a typology of four sharing business models that we call shared infrastructure providers, commoners, mission-driven platforms, and matchmakers (see Figure 1). Each type relies on distinct mechanisms of value creation and value capture, is confronted with different scalability potential, holds different societal promises and impacts, and must manage different potential controversies (see Table 2).

\section{Shared infrastructure providers}

Shared infrastructure providers are for-profit initiatives that create value by providing monetized, temporary access to a centralized pool of proprietary resources (machine tools for DIYers, cars, bike, etc.). Individuals and professional clients can use the service as fee-paying members or on a pay-per-use basis. TechShop, a chain of digital fabrication workshops founded in 2006 in California, illustrates this type of initiative. Mark Hatch (2017), CEO \& Co-Founder of TechShop, explains: "TechShop is a membership-based, do-it-yourself fabrication studio. 'Membership-based' means you get access to it, just like a gymnasium or a health club. It's $\$ 125$ a month. 'Do-it-yourself' means you have all these amazing tools - machine tools, woodworking, glass, electronics - but you use the tools yourself $(\ldots) . "$

Similar logics abound in the mobility sector. Examples include Zipcar (an American car-sharing company founded in 2000) and analogous initiatives such as Communauto (Montreal), Car2go (Europe, US, Canada), as well as other types of mobility services offering bikes or scooters. These initiatives set up and manage a proprietary network of vehicles in urban areas. Members can access such services by paying a monthly or annual membership fee in addition to usage fees, and by using a technology device to book and unlock the cars.

To scale, they require a sufficient level of activity to ensure operational profitability, as well as significant financial resources. Initiatives may explore different development strategies depending on market maturity, need for operational control, and access to financial resources. When initiatives have access to significant financial resources, and when the need for fast growth is relatively low, internal growth strategies may be appropriate but risky. In the US, TechShop opted for an internal growth strategy, steadily growing its operating base across the country. However, TechShop failed to find a sustainable business model, due to the high cost of operating its studios, and in 2017, shut down all the US locations and declared bankruptcy. In parallel, TechShop started its international expansion by forming strategic partnerships with organizations willing to co-invest in the creation of new sites (see section on implications for established organizations). Four TechShop sites exist now in different cities around the world (Tokyo, Abu Dhabi, Paris, and Lille). 


\section{How to Create Value(s) in the Sharing Economy: Business Models, Scalability, and Sustainability Aurélien Acquier, Valentina Carbone, and David Massé}

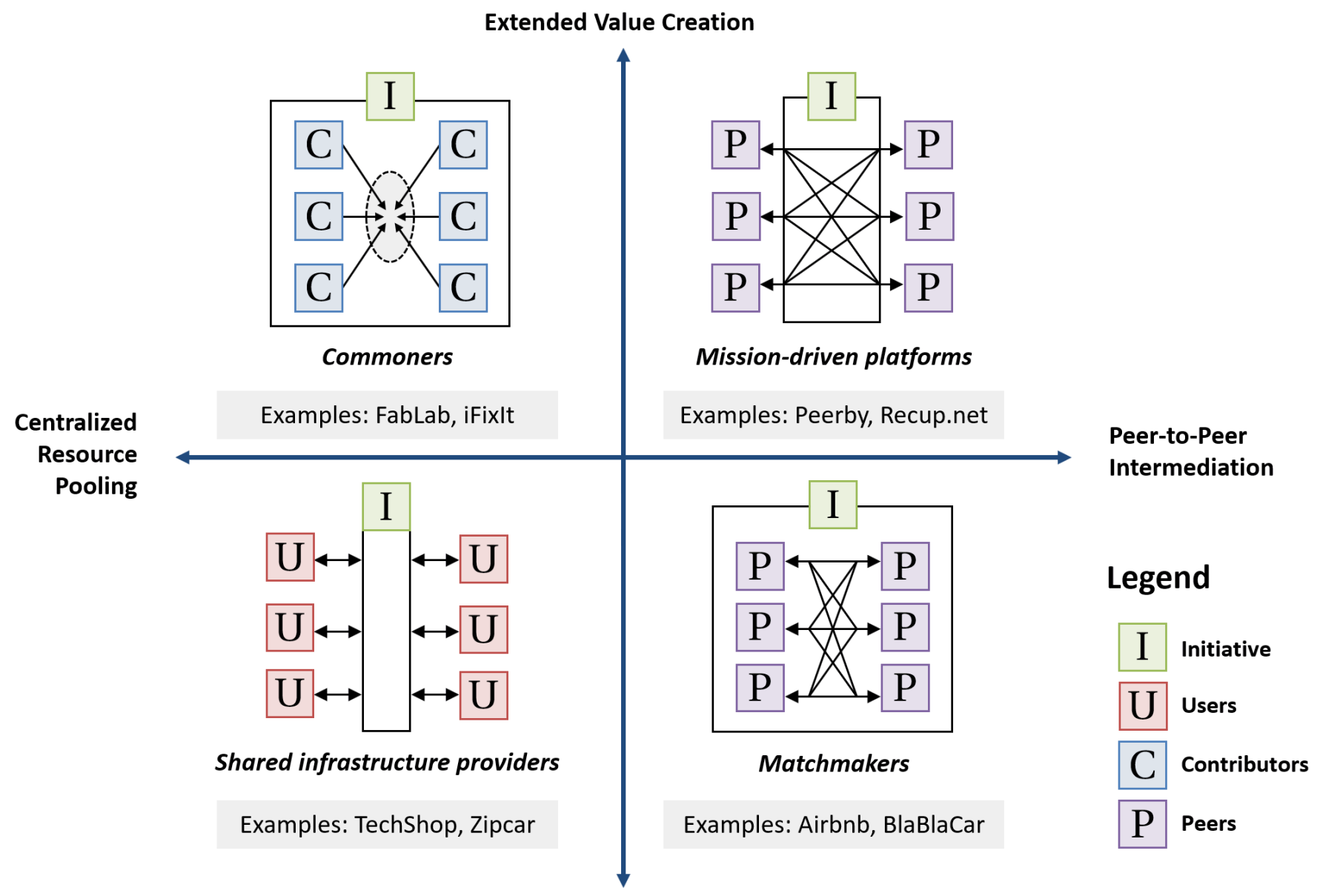

Economic Value Creation

Figure 1. Four business model configurations of sharing organizations

In order to expand faster or in more competitive, mature markets, initiatives can explore alliances, partnerships, or external growth strategies by acquiring competitors. In 2007, Zipcar (now the world's largest car-sharing company) merged with Flexcar (the oldest and second-largest car-sharing company in the US). The company then started its international expansion by acquiring Avancar in Spain in 2009 and Streetcar in the UK in 2010. Eventually, Zipcar itself was acquired by the rental company Avis Budget Group in 2013.

In terms of social and environmental promises, as shared infrastructure providers offer access instead of ownership and intensify resource use, they hold significant promise at the local/city level, where the current under-optimization of assets such as cars may create social and environmental problems. For example, shared mobility services may be particularly attractive for cities that wish to reduce inner-city congestion, de- crease pollution through more environmentally friendly engines, reduce city access to privately-owned vehicles, and promote multimodal and soft transportation modes such as bike-sharing (Cohen \& Kietzmann, 2014). Studies have shown that initiatives such as Zipcar or other car-sharing services tend to reduce private car ownership: by discouraging car purchases or substituting for private ownership, every car-sharing vehicle in the fleet replaces 9 to 13 privately-owned vehicles (Martin \& Shaheen, 2011). Accordingly, for public actors, developing such shared infrastructures may be part of a more general city innovation strategy (Cohen et al., 2016), opening the way for public/private partnerships to co-invest in "merit-based business models" (Cohen \& Kietzmann, 2014).

Despite such social and environmental promises, these organizations are likely to face controversies. Some studies on car sharing contest the existence of a 


\section{How to Create Value(s) in the Sharing Economy: Business Models, Scalability, and Sustainability Aurélien Acquier, Valentina Carbone, and David Massé}

Table 2. Overview of the four business model configurations of sharing organizations

\begin{tabular}{|c|c|c|c|c|}
\hline & $\begin{array}{l}\text { Shared Infrastructure } \\
\text { Providers }\end{array}$ & Commoners & Mission-Driven Platforms & Matchmakers \\
\hline Examples & $\begin{array}{l}\text { TechShop, Zipcar, } \\
\text { Communauto }\end{array}$ & Wikipedia, FabLab, iFixIt & Peerby, Mutum, Recup.net & Airbnb, BlaBlaCar \\
\hline $\begin{array}{l}\text { Value-creation } \\
\text { mechanisms }\end{array}$ & $\begin{array}{l}\text { Providing monetized access } \\
\text { to a centralized pool of } \\
\text { proprietary resources }\end{array}$ & $\begin{array}{l}\text { Creating and providing free } \\
\text { access to public goods }\end{array}$ & $\begin{array}{l}\text { Intermediating between } \\
\text { peers to promote a societal } \\
\text { cause }\end{array}$ & $\begin{array}{l}\text { Intermediating between } \\
\text { peers to develop } \\
\text { decentralized market } \\
\text { transactions }\end{array}$ \\
\hline $\begin{array}{l}\text { Value-capture } \\
\text { mechanisms }\end{array}$ & $\begin{array}{l}\text { - Membership fees } \\
\text { - Pay per use } \\
\text { - Public subsidies }\end{array}$ & $\begin{array}{l}\text { - Free work by community } \\
\text { members } \\
\text { - Public and private } \\
\text { donations } \\
\text { - Complementary for-profit } \\
\text { activities }\end{array}$ & $\begin{array}{l}\text { - Introduce market } \\
\text { mechanisms (advertising, } \\
\text { commissions, etc.) } \\
\text { compatible with the } \\
\text { mission } \\
\text { - Non-monetary } \\
\text { contributions from } \\
\text { members/founders }\end{array}$ & $\begin{array}{l}\text { - Commissions } \\
\text { - Freemium model } \\
\text { - Two-sided market } \\
\text { business models }\end{array}$ \\
\hline
\end{tabular}

\begin{tabular}{|c|c|c|c|c|}
\hline Scalability issues & $\begin{array}{l}\text { Building a capital-intensive } \\
\text { infrastructure through: } \\
\text { - Market concentration } \\
\text { (M\&A) } \\
\text { - Investment capital } \\
\text { - Public/private } \\
\text { partnerships } \\
\text { - Franchising }\end{array}$ & $\begin{array}{l}\text { Scaling the organization } \\
\text { through: } \\
\text { - Project economic } \\
\text { sustainability } \\
\text { - Community growth } \\
\text { Cause-related (non- } \\
\text { proprietary) scaling: } \\
\text { - "Free franchising" (charts, } \\
\text { rules, etc.) } \\
\text { - Launching a social } \\
\text { movement }\end{array}$ & $\begin{array}{l}\text { Overcoming low scalability } \\
\text { through: } \\
\text { - Hybrid arrangements } \\
\text { (combining economic and } \\
\text { social value creation) } \\
\text { - Access to financial capital } \\
\text { - Development of } \\
\text { professional skills } \\
\text { (digital/local } \\
\text { communities) }\end{array}$ & $\begin{array}{l}\text { Managing high scaling } \\
\text { potential through: } \\
\text { - constant sourcing of } \\
\text { supply and demand } \\
\text { - development of trust } \\
\text { among clients } \\
\text { - access to financial capital } \\
\text { - managing regulation and } \\
\text { social controversies }\end{array}$ \\
\hline $\begin{array}{l}\text { Social \& } \\
\text { environmental } \\
\text { promises/impacts }\end{array}$ & $\begin{array}{l}\text { Local societal } \\
\text { transformation towards } \\
\text { access-based economy }\end{array}$ & $\begin{array}{l}\text { Global cultural and societal } \\
\text { transformation towards } \\
\text { open-access, DIY, } \\
\text { reparability }\end{array}$ & $\begin{array}{l}\text { - Promises are high: } \\
\text { intermediation is a tool to } \\
\text { generate societal impacts }\end{array}$ & $\begin{array}{l}\text { - Promises are low: } \\
\text { initiatives may capitalize } \\
\text { on unintended } \\
\text { externalities }\end{array}$ \\
\hline
\end{tabular}

"community logic" among Zipcar users, and suggest that market expectations prevail instead (Bardhi \& Eckhardt, 2012). In the same vein, shared infrastructure providers may be criticized for using social and environmental promises as an entrepreneurial subterfuge, using "pseudo-sharing" as a way to hide the true capitalist nature of the field, and to facilitate big-business centralization. Accordingly, shared infrastructure providers should be cautious with their environmental or social claims and pay particular attention to measuring such impacts.

\section{Commoners}

Commoners create and provide free access to public goods. They are mostly non-profit initiatives that pool resources and skills in order to make them available to the greatest number. Wikipedia constitutes a central reference for many of these initiatives. Through their initiatives, they promote an ideology based on alternative and non-market values, such as open-knowledge, do it yourself (DIY), and the democratization of resources enabling decentralized production, repair, free contribution, and free access. In such initiatives, value is created by and for the community or the initiative's ecosystem. While their ideology is strongly rooted in the digital culture (Turner, 2006), these initiatives are found in both the digital and physical worlds.

Initiatives such as iFixit (a US private company founded in 2003) or Comment Réparer (a French non-profit equivalent started in 2011) replicate a similar logic for repairing consumer goods. These initiatives build online communities of individuals searching for or offering solutions to repair goods. Their website aggregates 


\section{How to Create Value(s) in the Sharing Economy: Business Models, Scalability, and Sustainability Aurélien Acquier, Valentina Carbone, and David Massé}

these decentralized interactions and oversees an editorial process to develop free repair guides, developed by community members and made accessible to all. Both initiatives explicitly promote their project as a way to fight against waste (in particular e-waste) and planned obsolescence, and to boost the circular economy.

Fab labs (fabrication laboratories) offer an example of commoners in the physical world, oriented towards production. The movement appeared in the late 1990s, spearheaded by Neil Gershenfeld, a professor at MIT who wanted to make digital production tools widely available for people to fabricate "almost anything" (Gershenfeld, 2011). Today, "fab labs are a global network of local labs, enabling invention by providing access to tools for digital fabrication" (MIT, 2012), particularly computer-controlled machine tools (such as 3D printers) for the design and production of physical objects. As of February 2019, there are more than 1000 fab labs located in more than 40 countries (Fablabs.io, 2019). And, next to fab labs as defined by MIT, related initiatives have emerged under different labels such as hackerspaces or makerspaces.

Commoners develop specific business models, where value is created by and for the community. Thanks to contributors' voluntary work (members freely give their time, energy, and skills), operational costs are reduced. Most financial needs are related to the central coordination of the initiative and the development and running of its operational infrastructure. These costs can grow significantly as the initiative develops or when it involves physical assets, such as fab labs or makerspaces.

Due to the non-profit character of such initiatives, finding sustainable business models can be a challenge for commoners, which explains why many such initiatives remain local and fail to scale. They may capture value by combining various indirect approaches. First, commoners may look for support from third parties (public authorities, universities, private donors, etc.) who provide financial or physical resources (premises, machines, etc.). A second mechanism consists of introducing complementary for-profit activities to financially support the mission. For example, iFixit earns money through its online shop, by selling toolkits or spare parts. Third, the initiatives can move away from a completely open and free model by introducing monthly member subscriptions. This has been done by many non-university fab labs to cover operating expenses (electricity, rent, etc.). The challenge is to maintain these market mechanisms within acceptable boundaries to avoid shifting into a market and professional logic (which would be more characteristic of shared infrastructure providers) and compromise the mission of openness that characterizes commoners.

Commoners aspire to have a global impact, and they often position their undertaking within a broader political and social movement whose scope is not confined to an isolated and local initiative. When commoner initiatives are resource hungry (such as fab labs or physical spaces), they may explore forms of non-proprietary scaling or "free-franchising model". For example, building on the MIT Fab Lab, Neil Gershenfeld developed a worldwide network of fab labs following a charter (MIT, 2012) that stipulates a certain number of principles (openness, collaboration, free equipment, ownership of inventions, etc.) that members have to comply with to belong to the network.

As commoners seek change at societal and cultural levels, their action often entails changes related to copyright laws, access and creative commons. Consequently, they generate political and social controversies, and they have to engage in political struggles. iFixit, for example, fights for a "right to repair": "Ownership means you should be able to open, hack, repair, upgrade, or tie bells on it. Once you've paid money for a product, the manufacturer shouldn't be able to dictate how you use it - it's yours." (iFixit, 2019). Other controversies include managing legal conflicts with incumbent firms because of closed business models (as suggested by the history of open source software in the computer industry), the tensions between non-market and market logics as the initiative grows, and finding a workable balance between the non-profit orientation and for-profit activities, to avoid organizational drift towards a shared infrastructure provider model.

\section{Mission-driven platforms}

Mission-driven platforms intermediate between peers to promote a societal cause. Like commoners, they pursue a mission to transform the economy and to engender new practices in the areas of consumption, exchange, and relationships. They may promote various societal causes, such as reducing waste, cutting out supply chain intermediaries, or re-creating social links among strangers or neighbours. In spite of these commonalities, the central mechanism they use to make a social impact differs from commoners: instead of creating a centralized pool of resources accessible to anyone, they create value by organizing local decentralized exchanges among individuals, harnessing the power of local peer-to-peer interactions. Mission-driven platforms may take the form of non-profit, for-profit, or hybrid structures. 


\section{How to Create Value(s) in the Sharing Economy: Business Models, Scalability, and Sustainability Aurélien Acquier, Valentina Carbone, and David Massé}

Many initiatives aim to reduce waste. Recup.net is a non-profit example of such initiatives. Launched in 2001 by a software developer working in an investment bank but wanting to promote environmental values outside his professional activities, it is a simple Internet platform whose aim is to facilitate gifting among peers and avoid generating unnecessary waste. Fighting against food waste, Too Good To Go is an application developed in 2016 that enables restaurants and hotels to make unsold food available for a fraction of the price before it gets thrown away. In the same vein, Couchsurfing was launched in 2003 as a free online hospitality network, where global travellers offer each other accommodation free of charge in their homes (Molz, 2012). This "free version of Airbnb" claims a global community of 400,000 hosts and 4 million members. Other initiatives aim to create social links in neighbourhoods by facilitating the borrowing of objects or free services among members of a given community. Examples such as ShareVoisins and Mutum in France, or Peerby in the Netherlands fall into such a category. Launched in 2013, Peerby enables each user to lend or borrow objects from other members in the same geographic area. The platform claims that there is an $85 \%$ chance of finding the sought-after object free of charge within 30 minutes. In 2016, this 15-person start-up had more than 100,000 users across the Netherlands, Belgium, London and Berlin, and raised $€ 2.2$ million $(\sim 3.3$ million CAD in crowdfunding, out of $€ 3.7$ million $(\sim 55.5$ million $\mathrm{CAD}$ ) in total, to pursue its development.

For mission-driven platforms, the search for a business model often constitutes the stumbling block of the initiative. Purely non-profit models rest on voluntary contributions to meet operational needs. However, such models often fail to scale beyond a limited threshold. For example, Recup.net has been running for a decade and continues to run with 200 gifts and 15,000 views a day, but it has never scaled beyond that level. While they may raise funds through crowdfunding, they often struggle to find economically sustainable business models based on gifting and non-monetary transactions.

Intermediating peers also involves resources to develop dense local communities at the local level. Learning from local demand was also central for Peerby in efforts to scale up, as it was confronted with a huge imbalance between supply and demand: "We had probably 20 times as much supply as we had people requesting items" (CEO, Peerby). Peerby teams discovered that, while people were happy to supply material goods for free, demanders felt uncomfortable borrowing for free, preferring a monetary transaction which would allow them to expect a certain level of quality, availability, and convenience. To stimulate demand, Peerby decided to launch Peerby Go in 2016, a peer-to-peer renting platform involving monetary transactions which eventually grew much faster than the original lending platform.

Scaling the platform and keeping social innovation logics requires initiatives to select an appropriate governance model. Some actors currently explore how "platform cooperativism" (Scholz, 2016) could provide a relevant and coherent model of governance for mission-driven platforms, resting on collective ownership and democratic governance. For more classical governance structures, managers must select and choose financial partners that are compatible with the project's mission, which can be difficult with conventional venture capitalists. Couchsurfing experienced such problems in 2010, when it changed its legal status from a non-profit to a for-profit company and raised about $\$ 8$ million from venture capital, provoking contestation from users complaining about a mismatch between free transactions and the for-profit orientation of the company (Belk, 2014). To finance its development while preserving a strong focus on community and environmental logics, Peerby launched a crowdfunding campaign and raised $€ 2.2$ million ( $\sim \$ 3.3$ million CAD) in four days, with about $70 \%$ coming from its user community. Another issue for mission-driven platforms is to identify a business model that is economically sustainable and compatible with the values of the project.

To add to this managerial complexity, mission-driven platforms are also confronted with various controversies. First, their initial activism may be called into question as the organization grows. There is a typical tension for such initiatives between staying small and committed to a non-profit ideology or growing bigger and running the risk of mission drift (Battilana \& Dorado, 2010), falling in the matchmaker category (described below). While it maintains a strong environmental and community logic, Peerby could be criticized for distancing itself from "true" or "pure" sharing, as it introduced monetary transactions in addition to borrowing.

In view of these elements, the promise of mission-driven platforms to combine the scaling potential of platforms with a social mission proves both very promising and challenging. Initiatives must find ways to sustain hybridity over time, finding a third way between pure market logics (without a mission) and pure non-profit logics (with limited scaling potential). If they overcome 


\section{How to Create Value(s) in the Sharing Economy: Business Models, Scalability, and Sustainability Aurélien Acquier, Valentina Carbone, and David Massé}

the barriers to scaling, they may combine both scalability and strong social impact (Seelos \& Mair, 2017).

\section{Matchmakers}

Matchmakers intermediate between peers to develop decentralized market transactions. They are for-profit commercial platforms that build networks of individuals who can conduct transactions for goods or services on a peer-to-peer basis in the physical world (Evans \& Schmalensee, 2016). They begin by identifying a resource that is dispersed, under-exploited, and has a high sharing value. Instead of owning the productive assets needed for the service, they outsource most productive assets from peers, acting as a broker and taking a commission from the market exchanges they enable. In the transportation and hospitality sectors, matchmakers are platforms such as Uber, Lyft, BlaBlaCar, or Airbnb. These initiatives often promote a free-market ideology, fighting against the economic rents of established corporations. Within the continuum between "pure sharing" and "pure exchange" evidenced by Habibi and co-authors (2016), they definitely fall into the market-exchange logic.

Airbnb is an iconic example of an initiative that intermediates between peers to provide hospitality services. Started in 2007 as a private company, the platform lists over three million lodgings in 81,000 cities and 191 countries in 2019. While it remains a private company, its value is estimated at $\$ 30$ billion USD (more than Hilton and Hyatt combined, in 2017). Along with its exponential growth, the platform has generated major controversies because of its impact on urban housing markets and the regulation of short-term rentals, leading many cities such as New York, Paris, and Berlin to introduce administrative restrictions on short-term property rentals.

In the transportation sector, BlaBlaCar is a ridesharing platform. Founded in France in 2006 by Frederic Mazella, it connects drivers and passengers willing to travel together and share travel costs, mainly over long distances. With more than $\$ 300$ million USD raised, the company is one of Europe's best-funded startups, valued at $\$ 1.6$ billion USD at the end of 2015. It is now present in more than 20 countries, has more than 600 employees, and has a community of 60 million members.

Matchmakers have high scaling potential and are likely to generate massive impacts. These impacts are to be understood as externalities, meaning that they are unintended positive or negative economic, social, or envir- onmental consequences. While they rarely claim a social mission at the core of their organization (lower social promise), many matchmakers claim to generate positive externalities. For example, as the occupancy rate for its cars is 2.8 people (while the European average is 1.7), BlaBlaCar takes pride in its positive impacts on greenhouse gas emissions and energy use: "When you share your ride, you're directly helping to reduce CO2 emissions." (BlaBlaCar, 2019) While the actual story may be more nuanced (because of complex substitution effects with more energy efficient collective transportation), a European study shows that car-sharing can yield city-friendly and environmentally-friendly effects, when combined with other eco-transportation modes (public transport, bicycling or walking) (Loose, 2010). In the social dimension, one of the biggest controversies generated by matchmakers relates to the impacts of platform capitalism on work (Casilli, 2019). For-profit platforms are criticized for building quasimonopolistic market positions, exploiting regulatory voids, and leading to increased precariousness for selfemployed people and independent contractors who are highly dependent on platforms. The platforms are accused of using sophisticated algorithms to create new "digital economy feudalism" and externalizing welfare, social costs, responsibility, and risks to workers (Friedman, 2014; Redfearn, 2016; Slee, 2015). The affiliation of such initiatives with sharing economy values is thus met with skepticism, and these privately-owned platforms have been denounced for organizing forms of "pseudo-sharing" based on market mechanisms instead of social exchange and shared value creation.

Overall, because of their high scaling potential, matchmakers are confronted with massive social controversies and regulatory issues related to their intermediation power, the status of their workers, their effects on cities, or their economic impact on incumbent companies or professions (such as taxi vs. Uber drivers). While these platforms may claim various positive environmental and social benefits, such arguments need to be considered with caution, as they may be part of matchmakers' political strategies to respond to the social controversies they generate.

\section{Implications}

\section{Implications for sharing economy initiatives}

Our study has various implications for sharing economy entrepreneurs. We provide a framework for sorting out the complexity of the field. In a situation where external observers mostly focus on one dimension and refer to one particular subset of the sharing economy, 


\section{How to Create Value(s) in the Sharing Economy: Business Models, Scalability, and Sustainability Aurélien Acquier, Valentina Carbone, and David Massé}

we group the complexity of the sharing economy into four possible configurations of initiatives. While other sharing economy typologies have already been proposed, the purpose of many of them is descriptive, and they simply provide an empirical mapping of the field (Botsman \& Rogers, 2010; Owyang, 2014; Stokes et al., 2014). Consequently, they fail to provide guidance on the managerial and social issues behind the development of the sharing economy. In our model, each of the four categories is constructed according to variables based on value creation and value distribution/capture, providing clear managerial guidance to sharing economy entrepreneurs. Our model has some points in common with the more analytical typology proposed by Schor (2014), but we are much more specific in our explanation of the specificities of each configuration, what kind of value (economic, social, environmental) is created by sharing economy entrepreneurs, the scalability challenges they may face, and how value is captured and distributed in each type. By locating their initiative in the matrix, sharing economy entrepreneurs can understand which competitive, managerial, and social forces are likely to play a key role for them. Accordingly, our model provides guidance for sharing economy entrepreneurs to spot internal scalability issues and potential external controversies.

Sharing economy entrepreneurs can also use our framework to identify potential opportunities to hybridize their current model or to think about possible strategic trajectories. Sharing economy initiatives can combine features of different models, creating hybrid forms from the four we have depicted (See the example of The Food Assembly in Box 1). For example, commoners such as iFixit or Comment Réparer develop a common good that is accessible to all, but also use mechanisms typical of mission-driven platforms as they aggregate decentralized peer-to-peer interactions to sustain their cause. Similarly, Uber's stated efforts to develop fleets of autonomous self-driving cars would constitute a significant shift from a matchmaker configuration to that of a shared infrastructure provider. This move could be viewed as a response to the controversies and regulatory risk that currently characterize matchmakers, related to the uneven value distribution between the platform and its drivers, the externalization of social risks to drivers, and the related legal risks of seeing its drivers reclassified as salaried workers. However, owning a centralized infrastructure would mean that Uber is drastically changing its business model to compete with established companies such as Zipcar, with different (more capital intensive) scaling mechanisms and different environmental and social issues to manage.
Box 1. Combining market logic and societal impact: The example of "The Food Assembly"

The Food Assembly is a European-based platform created in 2010. It enables individuals to organize local micro-markets for food products by connecting local consumers with local food producers (within a maximum range of 250 kilometres) through a digital platform. Once a minimum number of pre-orders is reached, food producers agree to deliver the products at a given date in a physical place (the micro-market) where producers and consumers meet. Each micro-market is managed locally by a network member who is incentivized on the volume of transactions realized (through a fixed commission of $8.35 \%$ ). These individuals, who operate as self-employed entrepreneurs or associations, organize the local market by creating a local network of supply and demand, and regularly organizing a physical market in a localized physical space. Through its activity, The Food Assembly claims to create economic value and pursues a social mission to reduce the number of intermediaries between small agricultural producers and consumers, to promote local and small-scale farming and bypass large-scale distributors, and to give power and value back to consumers and local producers. To finance its activities and development, The Food Assembly takes a commission of $8.35 \%$ of the platform's turnover - about two to three times less than commissions from market platforms such as Uber or Airbnb in 2016. It also offers an equivalent commission to micro-market managers. The system is also meant to enable an increased margin for food producers who freely set their prices on the platform. In order to strengthen ties with its network, in 2016 The Food Assembly also distributed $10 \%$ of its capital as free shares to the network of micro-market managers.

This example suggests that our typology should also be used dynamically, to reveal trajectories for rapidly changing sharing economy business models. Observing the evolution of the field suggests that mission-driven platforms often experience tensions when seeking to scale up while preserving their mission. Mission-driven initiatives often run the risk of drifting towards a matchmaker approach, in particular when they introduce transactional logics that may weaken or run counter to community-based logics. In our sample, Peerby was 


\section{How to Create Value(s) in the Sharing Economy: Business Models, Scalability, and Sustainability Aurélien Acquier, Valentina Carbone, and David Massé}

started as a site for peers to borrow material goods for free. It eventually developed a rental site (Peerby Go) for commercial transactions among peers, generating commissions and scaling much faster. Likewise, BlaBlaCar was first created as a free carpooling site (covoiturage.fr) in 2006, and switched to a commission model in 2012. That moment was critical in the life of BlaBlaCar: while it enabled the site to finance its growth and to improve the service by decreasing cancellations, many long-time users strongly criticized this change, which went against the free spirit of carpooling. Such changes may be criticized as resulting from purely strategic and opportunistic calculations instead of the espoused mission: organizations such as BlaBlaCar or Peerby may be criticized by external stakeholders for building communities of users with a free model, before monetizing transactions in a second stage, once a critical mass and traffic have developed. Moreover, The Food Assembly may also see their legitimacy contested by competing models grounded in more activist or more commercial logic. The initiative had to face intense criticism in France from the older and activist AMAP movement (community-supported agriculture associations), which create a direct and offline relationship between a group of consumers who support one small farm (in this system, consumers also support agriculture-related risks). Strongly-rooted in non-market ideology, AMAP criticize the digital, professionalized, for-profit orientation of The Food Assembly, calling it an example of "pseudosharing". To avoid such criticisms, organizations need to pay particular attention to avoid being associated with the matchmaker category and avoid such drifts. BlaBlaCar constantly professes to be a "cost-sharing platform" and refuses to be identified as an "on-demand platform". By underscoring its environmental and societal mission - reducing congestion and pollution and creating a trust-based community - it seeks to differentiate itself from other highly criticized actors in the mobility sector, such as Uber.

\section{Implications for established companies}

The sharing economy is traditionally depicted as a disruptive trend, shaking up established organizations and raising serious threats for established businesses. Recent research (Cusumano, 2015; Kathan et al., 2016; Matzler et al., 2015; PWC, 2015) has highlighted the need for established companies to respond to sharing initiatives and adapt their business models, for example by improving service to compete with this new source of competition (Kibum \& Jeong-Dong, 2016). By bringing to light the multiple models and value-creation mechanisms of the sharing economy, our framework reveals opportunities for established companies to go bey- ond the sharing economy as a source of disruption and analyze the sharing economy as a field of potential opportunities to explore. Managers of established companies can explore each sharing economy logic while taking into account their different rationales, mechanisms, and potential benefits (cf. Table 3).

Shared infrastructure providers inspire established companies that want to explore service-driven innovation (Kastalli et al., 2013), exemplified by the access-based model. Providing access instead of selling a product requires new skills, such as complex resource-orchestration skills (due to the significant assets needed) as well as a shift towards a service mindset for organizations traditionally engaged in selling products (Matzler et al., 2015). Car manufacturers such as Peugeot and BMW are examples of companies that are exploring the product-service system (Tukker, 2004) business model by offering a short-term mobility solution through online car rental services, such as "Peugeot Rent" and "Drive Now", or by investing in mobility businesses (Peugeot bought a stake in Communauto in September 2016). In this way, they complement their traditional product offering with an on-demand service to satisfy users' mobility needs. Pursuing the same objective of business diversification, Leroy Merlin - a retailer present in Europe, Asia, and South America that specializes in construction materials, DIY, and gardening partnered with TechShop to open its first 2000 square metre collaborative production space near Paris in autumn 2015. This market-diversification strategy enables the company to explore a new service for independent professionals, target younger and more "high-tech" customers, and benefit from the expertise of a recognized player in the field of shared DIY spaces. It also creates new sales opportunities for the Leroy Merlin store located next to the TechShop space, by capturing new flows of potential DIY customers.

Commoners provide a source of inspiration for companies wishing to implement community-driven innovation by allowing internal and external stakeholders access to corporate resources. Using the commoners logic may help companies to improve their relationships with internal and external stakeholders, thus increasing the legitimacy of the organization, with the aim of expanding the service offering to customers and engaging employees in an innovation culture. This can be done by giving external stakeholders access to unused and unvalued resources. For example, the French national railway company (SNCF) launched "Open Gare", a project aimed at upgrading and revitalizing former and abandoned railway stations. By making these physical 


\section{How to Create Value(s) in the Sharing Economy: Business Models, Scalability, and Sustainability Aurélien Acquier, Valentina Carbone, and David Massé}

Table 3. Established companies and sharing logics

\begin{tabular}{|c|c|c|c|c|}
\hline & $\begin{array}{l}\text { Shared Infrastructure } \\
\text { Providers }\end{array}$ & Commoners & $\begin{array}{l}\text { Mission-Driven } \\
\text { Platforms }\end{array}$ & Matchmakers \\
\hline Examples & $\begin{array}{l}\text { - Peugeot (Peugeot } \\
\text { Rent), BMW (Drive } \\
\text { Now), Daimler } \\
\text { (Car2Go) } \\
\text { - Leroy-Merlin } \\
\text { (partnership with } \\
\text { TechShop) } \\
\text { - Marriott (Workspring) }\end{array}$ & $\begin{array}{l}\text { - } \text { SNCF (Open Gare) } \\
\text { - Castorama (Wiki for } \\
\text { Home) } \\
\text { - Renault, Air Liquide } \\
\text { (internal fab labs) }\end{array}$ & $\begin{array}{l}\text { - Patagonia (Worn-Wear } \\
\text { + partnership with eBay } \\
\text { for second-hand sales) } \\
\text { - Decathlon (Trocathlon) }\end{array}$ & $\begin{array}{l}\text { - Mercedes Benz } \\
\text { (Croove) } \\
\text { - Fnac (online peer-to- } \\
\text { peer platform) } \\
\text { - IKEA (car-sharing } \\
\text { partnership with } \\
\text { BlaBlaCar) }\end{array}$ \\
\hline Rationale & Service driven & Community driven & Sustainability driven & Competition driven \\
\hline $\begin{array}{l}\text { Key } \\
\text { mechanisms }\end{array}$ & $\begin{array}{l}\text { Develop for-profit } \\
\text { services based on } \\
\text { internal resources or } \\
\text { external partnerships }\end{array}$ & $\begin{array}{l}\text { Open the access to } \\
\text { corporate resources for } \\
\text { external and internal } \\
\text { stakeholders by: } \\
\text { - creating new resource } \\
\text { pools } \\
\text { - opening access to } \\
\text { existing but unvalued } \\
\text { resources }\end{array}$ & $\begin{array}{l}\text { Develop a community of } \\
\text { committed } \\
\text { users/customers to } \\
\text { promote corporate social } \\
\text { and environmental } \\
\text { values }\end{array}$ & $\begin{array}{l}\text { Business diversification } \\
\text { in sharing economy } \\
\text { activities } \\
\text { Develop partnerships } \\
\text { with sharing economy } \\
\text { companies to offer new } \\
\text { services }\end{array}$ \\
\hline $\begin{array}{l}\text { Potential } \\
\text { benefits }\end{array}$ & $\begin{array}{l}\text { - Market diversification } \\
\text { (exploring access- } \\
\text { based business } \\
\text { models) } \\
\text { - Commitment to } \\
\text { environmentally } \\
\text { efficient solutions }\end{array}$ & $\begin{array}{l}\text { - Enhanced corporate } \\
\text { reputation with } \\
\text { external stakeholders } \\
\text { - Increased service for } \\
\text { customers } \\
\text { - Foster employees' } \\
\text { motivation and a } \\
\text { culture of innovation }\end{array}$ & $\begin{array}{l}\text { - Strengthen/promote a } \\
\text { sustainable corporate } \\
\text { identity } \\
\text { - Enhance customer } \\
\text { service, increase } \\
\text { customer loyalty } \\
\text { - Build brand } \\
\text { communities } \\
\text { associated with social } \\
\text { and environmental } \\
\text { values }\end{array}$ & $\begin{array}{l}\text { - Market diversification } \\
\text { to platform business } \\
\text { models } \\
\text { - Enhanced service to } \\
\text { customers (logistics, } \\
\text { transport, etc.) }\end{array}$ \\
\hline
\end{tabular}

assets available to local associations, communities, startups, etc., the company allows and encourages the setting up of makerspaces, co-working spaces, and other collaborative schemes. Through this project, the SNCF saves money on maintenance and asset management, and improves its legitimacy by supporting local societal initiatives. And local stakeholders can develop collaborative projects without requiring huge investments. Taking inspiration from the Wikipedia model, Castorama, a French retailer of construction materials, DIY, and gardening products, launched "Wiki for Home" which aims to be France's largest free encyclopedia for home DIY knowledge and know-how. The platform places the brand at the core of a community of contributors and users who advise each other while sourcing their DIY material from Castorama. Managing such a community of young and digitally-savvy consumers engaged in the new reciprocal service provision through the wiki, has also enlarged the brand's traditional base of customers. 


\section{How to Create Value(s) in the Sharing Economy: Business Models, Scalability, and Sustainability Aurélien Acquier, Valentina Carbone, and David Massé}

Mission-driven platforms are likely to inspire companies who wish to promote their commitment to sustainability and shared-value creation by developing brand communities with strong values. For example, the outdoor clothing company Patagonia, building from its older inhouse initiative "Worn Wear", partnered with eBay in 2011 to create an online marketplace for consumers to buy and sell used Patagonia clothing. Patagonia does not make any direct profit from these second-hand product sales, but it fosters its mission to protect the environment by increasing the usage of its products via peer-to-peer resale. An initiative like this also makes the brand's products available to buyers who may not have been able to afford them otherwise. Similarly, in 2014, Decathlon, one of the world's largest sporting goods retailers, opened an online version their "Trocathlon" initiative (a consignment sale for sports items held twice a year in their stores' parking lots) to make the service available year-round, commission free. Customers can buy and sell secondhand equipment and earn vouchers to spend at the retailers' physical and online shops. First, the company helps its customers manage the lifecycle of their sports equipment, favouring the recirculation of goods and thus reducing their environmental impact through extended use. Second, this initiative increases sales and customer loyalty, as consumers who improve their sport skills are encouraged to sell their old equipment through the platform and reinvest in new, upmarket and better-performing equipment.

Finally, matchmakers may appeal to companies exploring new areas of competition and see business opportunities in the sharing economy through peer intermediation (Evans \& Schmalensee, 2016). Established businesses may take advantage of their reputation in established markets to become a trusted third party in the peer-to-peer market and compete with sharing economy companies. For example, Mercedes-Benz (a Daimler brand) launched Croove, a peer-to-peer rental platform in Germany. This type of initiative directly competes with other peer-to-peer initiatives in car sharing. It may also be a way to explore the future of mobility and new market developments. Such peer-to-peer platforms may also serve as an incentive to purchase, by showing how occasionally renting out one's new car may help pay back the initial investment. When a company already has an online marketplace, it is easy to open it to peer-to-peer exchanges and further develop customer loyalty by offering the possibility to intensify the usage/exchange of goods. For example, the French electronics and cultural retail chain La Fnac opened its online marketplace to individuals and companies wishing to resell their CDs, books, computers, etc. New cus- tomer services can also be pursued through the matchmaker logic by developing partnerships with sharing economy companies. In Europe, IKEA partnered with BlaBlaCar to launch a specific car-pooling service to tackle a major obstacle for city dwellers: transport from the city to their outlets. By making it easier to travel back and forth to stores, IKEA is attracting new customers and improving customer service.

\section{Implications for policymakers}

The sharing economy constitutes a challenge for policymakers. Impacts of the sharing economy vary according to the levels (city/national/transnational) and types of actors involved. Governments have to combine contradictory objectives: act in the public interest, take into consideration customers' appetite for peer-to-peer services, stimulate societal innovation, favour the growth of sharing economy companies while ensuring fairness for incumbents, limit and regulate potentially negative externalities related to the rise of independent work on digital platforms, etc. Moreover, the co-existence of a great variety of profiles and value-creation mechanisms in the sharing economy further complicates the task for regulators. Our four-part framework for the sharing economy field gives rise to differentiated recommendations for public bodies for either regulating, sustaining, or shaping the sharing economy.

1. Regulate: Matchmakers are quite controversial in terms of their social impact, as shown by repeated tensions and struggles related to the regulation of platforms in the hospitality and on-demand mobility sectors. This new platform economy has global economic impacts: it is reshaping the boundaries between the professional and domestic spheres, transforming work and employment relationships, and raising new issues in terms of taxation, insurance, customer protection and trust, labour law, and welfare protection (Redfearn, 2016). Complex questions arise about the legal and social responsibilities of these platforms, as they tend to externalize responsibilities to participants. Because of their global scale and their capacity to grow exponentially, matchmakers' social and environmental impacts can be enormous, on a national or transnational scale. For governments, the challenge is to better assess how matchmakers produce positive or negative externalities and build their expertise in this area, which includes encouraging independent studies on the environmental and social impacts of platforms, accessing data from platforms and producing external data, promoting virtuous practices to encourage positive externalities or regulating to reduce the negative ones. 


\section{How to Create Value(s) in the Sharing Economy: Business Models, Scalability, and Sustainability Aurélien Acquier, Valentina Carbone, and David Massé}

2. Sustain: As activists seeking to promote a cause, mission-driven platforms and commoners have the potential to introduce major environmental and social innovations, but their development is often inhibited by difficulties in raising financial resources or identifying adequate revenue models to support growth, as well as by the lack of certain skills, including community management/information systems and solutions development. For example, the promises of greater circulation of goods, reduced planned obsolescence and more responsible consumption announced by some non-profit lending and gifting platforms are hampered by technical and scalability issues. Organizations with hybrid governance models seem better able to overcome such challenges, by combining the activist logic of the mission-driven platforms and the commercial logic of the matchmakers while mastering the rules of the game of the digital sphere and developing the competencies required to deploy and scale up their platforms. Governments, as well as educational institutions (business, engineering, or design schools) and investors could encourage cross-fertilization between social entrepreneurship and the peer-topeer digital world through multiple actions, such as dedicated incubators, tools and policies for funding, and collaborative projects between educational institutions.

3. Shape: With their focus on the access economy, both shared infrastructure providers and commoners are innovative spaces that combine social and technical innovations. Commoners also promote an ideology based on open knowledge, public goods and DIY, calling for democratic governance and open organizational models. These initiatives are often rooted at a more local level and may have strong impacts at the level of the community, city or region. For example, the project of Barcelona Fab City was born in 2014 as a partnership between the Barcelona City Council and the Barcelona Fab Lab, with the objectives of stimulating local creativity and transforming cities into productive hubs using digital fabrication technologies. Likewise, shared mobility services may be financially supported by cities that co-invest in such projects as part of their transportation policies. As a result, shared infrastructure providers and commoners may be shaped by local authorities (cities/regions) to promote policies in line with their local economic, environmental, and social strategies.

\section{Conclusion}

We have identified four different business model configurations that testify to the variety of profiles, promises, and postures adopted by sharing economy initiatives. Each configuration is characterized by specific economic, social, and environmental value creation and distribution mechanisms, and internal tensions that need to be managed to achieve sustainable growth and cope with controversial issues. Our model has important implications for the management of sharing initiatives and for the management of established organizations, which may learn how to integrate the sharing economy logic into the core of their own business. Our results also enlighten policymakers on how to regulate and support the growth of the sharing economy, according to its sustainability implications and society-level transformations.

\section{About the Authors}

Aurélien Acquier is a Professor in the Management Department at ESCP Europe, Paris Campus. He teaches corporate strategy and organizational dynamics. He is the Scientific Co-Director of the ESCP Europe - Deloitte Chair on Circular Economy. In collaboration with various national and multinational companies, his research focuses on the relationships between sustainable development, corporate strategy, and institutional change.

Valentina Carbone is a Professor in the Information and Operations Management Department at ESCP Europe, Paris Campus. She teaches supply-chain management and sustainable business models. She is the Scientific Co-Director of the ESCP Europe Deloitte Chair on Circular Economy. Her research deals with sustainable supply-chain management, sharing and circular economy business models, and corporate social responsibility (CSR).

David Massé is an Associate Professor and Head of the Economics and Management Group at Télécom ParisTech, and he is a Researcher at Institut interdisciplinaire de l'innovation (CNRS-UMR 9217). His main research interests are creative industries, the sharing economy, and digital innovation management. 


\section{How to Create Value(s) in the Sharing Economy: Business Models, Scalability, and Sustainability Aurélien Acquier, Valentina Carbone, and David Massé}

\section{References}

Acquier, A., Carbone, V., \& Massé, D. 2017. A quoi pensent les institutions? Theorisation et institutionalisation du champ de l'economie collaborative. Revue française de gestion, 4(265): 25-50.

Acquier, A., Carbone V., \& Massé, D. 2016. Les mondes de l'économie collaborative: une approche par les modèles économiques. IDDRI Research Papers - Projet PICO. Paris: IDDRI.

Acquier, A., Daudigeos, T., \& Pinkse, J. 2017. Promises and Paradoxes of the Sharing Economy: An Organizing Framework. Technological Forecasting and Social Change, 125: 1-10. https://doi.org/10.1016/j.techfore.2017.07.006

Bardhi, F., \& Eckhardt, G. M. 2012. Access-Based Consumption: The Case of Car Sharing. Journal of Consumer Research, 39(4): 881-898. https://doi.org/10.1086/666376

Barnes, S. J., \& Mattsson, J. 2016. Understanding Current and Future Issues in Collaborative Consumption: A Four-Stage Delphi Sstudy. Technological Forecasting and Social Change, 104: 200-211. https://doi.org/10.1016/j.techfore.2016.01.006

Battilana, J., \& Dorado, S. 2010. Building Sustainable Hybrid Organizations: The Case of Commercial Microfinance Organizations. Academy of Management Journal, 53(6): 1419-1440. https://doi.org/10.5465/AMJ.2010.57318391

Belk, R. 2014. Sharing versus Pseudo-Sharing in Web 2.0. Anthropologist, 18(1): 7-23.

https://doi.org/10.1080/09720073.2014.11891518

Benkler, Y. 2004. Sharing Nicely: On Shareable Goods and the Emergence of Sharing as a Modality of Economic Production. The Yale Law Journal, 114(2): 273-358.

https://doi.org/10.2307/4135731

BlaBlaCar. 2019. BlaBlaCar Contribution to Climate Change. BlaBlaCar.in. Accessed February 13, 2019: https://blog.blablacar.in/blablalife/reinventingtravel/environment/blablacar-contribution-climate-change

Böcker, L., \& Meelen, T. 2017. Sharing for People, Planet or Profit? Analysing Motivations for Intended Sharing Economy Participation. Environmental Innovation and Societal Transitions, 23: 28-39.

https://doi.org/10.1016/j.eist.2016.09.004

Boons, F., \& Lüdeke-Freund, F. 2013. Business Models for Sustainable Innovation: State-of-the-Art and Steps Towards a Research Agenda. Journal of Cleaner Production, 45: 9-19. https://doi.org/10.1016/j.jclepro.2012.07.007

Botsman, R., \& Rogers, R. 2010. What's Mine Is Yours: How Collaborative Consumption Is Changing the Way We Live. London: Collins.

Botsman, R. 2013. The Sharing Economy Lacks A Shared Definition. Fast Company, November 21, 2013. Accessed March 25, 2017: http://www.fastcompany.com/3022028/the-sharing-economylacks-a-shared-definition

Bowman, C., \& Ambrosini, V. 2000. Value Creation Versus Value Capture: Towards a Coherent Definition of Value in Strategy. British Journal of Management, 11(1): 1-15. https://doi.org/10.1111/1467-8551.00147

Casilli, A. A. 2019. En attendant les robots - Enquête sur le travail du clic. Paris: Seuil.
Chase, R. 2015. Peers Inc: How People and Platforms Are Inventing the Collaborative Economy and Reinventing Capitalism. New York: PublicAffairs.

Cockayne, D. G. 2016. Sharing and Neoliberal Discourse: The Economic Function of Sharing in the Digital On-Demand Economy. Geoforum, 77: 73-82. http://doi.org/10.1016/j.geoforum.2016.10.005

Cohen, B., Almirall, E., \& Chesbrough, H. 2016. The City as a Lab: Open Innovation Meets the Collaborative Economy. California Management Review, 59(1): 5-13. https://doi.org/10.1177/0008125616683951

Cohen, B., \& Kietzmann, J. 2014. Ride On! Mobility Business Models for the Sharing Economy. Organization \& Environment, 27(3): 279-296.

https://doi.org/10.1177/1086026614546199

Cusumano, M. A. 2015. How Traditional Firms Must Compete in the Sharing Economy. Communications of the ACM, 58(1): 32-34. https://doi.org/10.1145/2688487

Demailly, D., \& Novel, A. S. 2014. The Sharing Economy: Make It Sustainable. Studies No. 03/14. Paris: IDDRI.

Eckhardt, G. M., \& Bardhi, F. 2016. The Relationship between Access Practices and Economic Systems. Journal of the Association for Consumer Research, 1(2): 210-225.

http://doi.org/10.1086/684684

Evans, D. S., \& Schmalensee, R. 2016. Matchmakers: The New Economics of Multisided Platforms. Boston, MA: Harvard Business Review Press.

Evans, P. C., \& Gawer, A. 2016. The Rise of the Platform Enterprise. New York: The Center for Global Enterprise.

Fablabs.io. 2019. About Fablabs.io. Fablabs.io. Accessed February 13, 2019:

https://www.fablabs.io/about

Frenken, K., \& Schor, J. 2017. Putting the Sharing Economy into Perspective. Environmental Innovation and Societal Transitions, 23: 3-10.

https://doi.org/10.1016/j.eist.2017.01.003

Fréry, F., Lecocq, X., \& Warnier, V. 2015. Competing with Ordinary Resources. MIT Sloan Management Review, 26(3): 69-77.

Friedman, G. 2014. Workers without Employers: Shadow Corporations and the Rise of the Gig Economy. Review of Keynesian Economics, 2(2): 171-188. https://doi.org/10.4337/roke.2014.02.03

Gallie, W. B. 1955. Essentially Contested Concepts. Proceedings of the Aristotelian Society, 56(1): 167-198. https://doi.org/10.1093/aristotelian/56.1.167

Gansky, L. 2012. The Mesh: Why the Future of Business Is Sharing. New York: Portfolio.

Gershenfeld, N. 2011. Fab: The Coming Revolution on Your DesktopFrom Personal Computers to Personal Fabrication. New York: Basic Books Inc.

Godelnik, R. 2014. Why Uber is Not Part of the Sharing Economy. Triple Pundit, December 12, 2014: http://www.triplepundit.com/2014/12/uber-not-part-sharingeconomy 


\section{How to Create Value(s) in the Sharing Economy: Business Models, Scalability, and Sustainability Aurélien Acquier, Valentina Carbone, and David Massé}

Guttentag, D. 2015. Airbnb: Disruptive Innovation and the Rise of an Informal Tourism Accommodation Sector. Current Issues in Tourism, 18(12): 1192-1217.

https://doi.org/10.1080/13683500.2013.827159

Habibi, M. R., Kim, A., \& Laroche, M. 2016. From Sharing to Exchange: An Extended Framework of Dual Modes of Collaborative Nonownership Consumption. Journal of the Association for Consumer Research, 1(2): 277-294. https://doi.org/10.1086/684685

Hatch, M. 2017. The Blueprint Talk with Mark Hatch. Theblueprint.com, Accessed March 28, 2017.

Heinrichs, H. 2013. Sharing Economy: A Potential New Pathway to Sustainability. GAIA - Ecological Perspectives for Science and Society, 22(4): 228-231. https://doi.org/10.14512/gaia.22.4.5

IFixit. 2019. We Have the Right to Repair Everything We Own iFixit.org. Accessed February 13, 2019: https://ifixit.org/right

John, N. A. 2013. Sharing and Web 2.0: The Emergence of a Keyword. New Media \& Society, 15(2): 167-182. https://doi.org/10.1177/1461444812450684

Kastalli, I. V., Van Looy, B., \& Neely, A. 2013. Steering Manufacturing Firms towards Service Business Model Innovation. California Management Review, 56(1): 100-123.

https://doi.org/10.1525/cmr.2013.56.1.100

Kathan, W., Matzler, K., \& Veider, V. 2016. The Sharing Economy: Your Business Model's Friend or Foe? Business Horizons, 59(6): 663-672.

https://doi.org/10.1016/j.bushor.2016.06.006

Kenney, M., \& Zysman, J. 2016. The Rise of the Platform Economy. Issues in Science and Technology, 32(3): 61-69.

Kibum, K., \& Jeong-Dong, L. 2016. The Emergence of the Sharing Economy: The Response Strategies of Preexisting Taxi Industry Affected by Uber's Disruption. STI Policy Review, 7(2): 60-84.

Kohtala, C., \& Bosqué, C. 2014. The Story of MIT-Fablab Norway: Community Embedding of Peer Production. Journal of Peer Production, 5 : 1-8.

Kortmann, S., \& Piller, F. 2016. Open Business Models and ClosedLoop Value Chains. California Management Review, 58(3): 88-108.

Kostakis, V., \& Bauwens, M. 2014. Network Society and Future Scenarios for a Collaborative Economy. London: Palgrave Macmillan.

Lepak, D. P., Smith, K. G., \& Taylor, M. S. 2007. Value Creation and Value Capture: A Multilevel Perspective. Academy of Management Review, 32(1): 180-194. https://doi.org/10.5465/amr.2007.23464011

Lessig, L. 2008. Remix: Making Art and Commerce Thrive in the Hybrid Economy. London: Penguin Press.

Loose, W. 2010. The State of European Car-Sharing. European Project Momo No. Final Report D 2.4 Work Package 2. Brussels: Intelligent Energy Europe, European Commission.

Mair, J., \& Reischauer, G. 2017. Capturing the Dynamics of the Sharing Economy: Institutional Research on the Plural Forms and Practices of Sharing Economy Organizations. Technological Forecasting and Social Change, 125: 11-20. https://doi.org/10.1016/j.techfore.2017.05.023
Martin, C. J. 2016. The Sharing Economy: A Pathway to Sustainability or a Nightmarish Form of Neoliberal Capitalism? Ecological Economics, 121: 149-159. https://doi.org/10.1016/j.ecolecon.2015.11.027

Martin, E., \& Shaheen, S. 2011. The Impact of Carsharing on Household Vehicle Ownership. ACCESS Magazine, 1(38): 22-27.

Matzler, K., Veider, V., \& Kathan, W. 2015. Adapting to the Sharing Economy. MIT Sloan Management Review, 56(2): 71-77.

McLaren, D., \& Agyeman, J. 2015. Sharing Cities: A Case for Truly Smart and Sustainable Cities. Cambridge, MA: MIT Press.

Meelen, T., \& Frenken, K. 2015. Stop Saying Uber Is Part of The Sharing Economy. Fast Company, January 14, 2015: https://www.fastcoexist.com/3040863/stop-saying-uber-is-partof-the-sharing-economy

MIT. 2012. The Fab Charter. Cambridge, MA: MIT Center for Bits and Atoms. Accessed February 13, 2019: http://fab.cba.mit.edu/about/charter/

Molz, J. G. 2012. CouchSurfing and Network Hospitality: It's Not Just About the Furniture. Hospitality \& Society, 1(3): 215-225. https://doi.org/10.1386/hosp.1.3.215_2

Morozov, E. 2014. Don't Believe the Hype: The "Sharing Economy" Masks a Failing Economy. The Guardian, September 28, 2014: http://www.theguardian.com/commentisfree/2014/sep/28/sharin g-economy-internet-hype-benefits-overstated-evgeny-morozov

Muñoz, P., \& Cohen, B. 2017. Mapping out the Sharing Economy: A Configurational Approach to Sharing Business Modeling. Technological Forecasting and Social Change, 125: 21-37. https://doi.org/10.1016/j.techfore.2017.03.035

Murillo, D., Buckland, H., \& Val, E. 2017. When the Sharing Economy Becomes Neoliberalism on Steroids: Unravelling the Controversies. Technological Forecasting and Social Change, 125: 66-76. https://doi.org/10.1016/j.techfore.2017.05.024

O'Toole, J., \& Vogel, D. 2011. Two and a Half Cheers for Conscious Capitalism. California Management Review, 53(3): 60-76. https://doi.org/10.1525/cmr.2011.53.3.60

Owyang, J. 2014. Framework: Collaborative Economy Honeycomb. Web-Strategist.com, May 5, 2014:

http://www.web-strategist.com/blog/2014/05/05/frameworkcollaborative-economy-honeycomb-osfest14/

Porter, M. E., \& Kramer, M. R. 2011. Creating Shared Value. Harvard Business Review, 89(1/2): 62-77.

PWC. 2015. The Sharing Economy. Consumer Intelligence Series. London: PricewaterhouseCoopers (PWC).

http://www.pwc.com/us/en/technology/publications/assets/pwc -consumer-intelligence-series-the-sharing-economy.pdf

Redfearn, R. L. 2016. Sharing Economy Misclassification: Employees and Independent Contractors in Transportation Network Companies. Berkeley Technology Law Journal, 31: 1023-1034. https://doi.org/10.15779/Z38RZ8J

Scholz, T. 2016. Platform Cooperativism. Challenging the Corporate Sharing Economy. New York: Rosa Luxemburg Stiftung.

Schor, J. 2014. Debating the Sharing Economy. Great Transition Initiative, October 2014. Accessed March 25, 2017: http://greattransition.org/publication/debating-the-sharingeconomy 


\section{How to Create Value(s) in the Sharing Economy: Business Models, Scalability, and Sustainability Aurélien Acquier, Valentina Carbone, and David Massé}

Schor, J. B., Walker, E. T., Lee, C. W., Parigi, P., \& Cook, K. 2015. On the Sharing Economy. Contexts, 14(1): 12-19.

https://doi.org/10.1177/1536504214567860

Seelos, C., \& Mair, J. 2007. Profitable Business Models and Market Creation in the Context of Deep Poverty: A Strategic View. The Academy of Management Perspectives, 21(4): 49-63.

https://doi.org/10.5465/AMP.2007.27895339

Seelos, C., \& Mair, J. 2017. Innovation and Scaling for Impact: How Effective Social Enterprises Do It. Stanford, CA: Stanford Business Books.

Slee, T. 2015. What's Yours Is Mine: Against the Sharing Economy. New York: OR Books.

Smith, A. 2016. Shared, Collaborative and On Demand: The New Digital Economy. Pew Research Center, May 19, 2016: http://www.pewinternet.org/2016/05/19/the-new-digitaleconomy/

Stephany, A. 2015. The Business of Sharing: Making It in the New Sharing Economy. London: Palgrave Macmillan.

Stokes, K., Clarence, E., Anderson, L., \& Rinne, A. 2014. Making Sense of the UK Collaborative Economy. London: NESTA Collaborative Lab.

http://www.nesta.org.uk/publications/making-sense-ukcollaborative-economy

Sundararajan, A. 2016. The Sharing Economy: The End of Employment and the Rise of Crowd-Based Capitalism. Cambridge, MA: The MIT Press.

Teece, D. J. 2010. Business Models, Business Strategy and Innovation. Long Range Planning, 43(2-3): 172-194.

https://doi.org/10.1016/j.lrp.2009.07.003

Tukker, A. 2004. Eight Types of Product-Service System: Eight Ways to Sustainability? Experiences from SusProNet. Business Strategy and the Environment, 13(4): 246-260.

https://doi.org/10.1002/bse.414

Turner, F. 2006. From Counterculture to Cyberculture - Stewart Brand, The Whole Earth Network, and the Rise of Digital Utopianism. Chicago: University of Chicago Press.

Voytenko Palgan, Y., Zvolska, L., \& Mont, O. 2017. Sustainability Framings of Accommodation Sharing. Environmental Innovation and Societal Transitions, 23: 70-83.

https://doi.org/10.1016/j.eist.2016.12.002

Yunus, M., Moingeon, B., \& Lehmann-Ortega, L. 2010. Building Social Business Models: Lessons from the Grameen Experience. Long Range Planning, 43(2-3): 308-325.

https://doi.org/10.1016/j.lrp.2009.12.005

Zott, C., \& Amit, R. 2010. Business Model Design: An Activity System Perspective. Long Range Planning, 43(2-3): 216-226.

https://doi.org/10.1016/j.lrp.2009.07.004 


\section{How to Create Value(s) in the Sharing Economy: Business Models, Scalability, and Sustainability Aurélien Acquier, Valentina Carbone, and David Massé}

Appendix 1. Sample of people interviewed at the collaborative initiatives

\begin{tabular}{|c|c|c|c|c|c|}
\hline Project Name & $\begin{array}{l}\text { Number and Title } \\
\text { of Interviewees }\end{array}$ & $\begin{array}{l}\text { Type } \\
\text { of Practice }\end{array}$ & $\begin{array}{l}\text { Interview } \\
\text { Location }\end{array}$ & Date & Duration \\
\hline Recup.net & 1 Founder & Donation & Paris & $27 / 03 / 15$ & 79 \\
\hline Co-Recyclage & 1 Co-Founder & Donation & Paris & $14 / 04 / 15$ & 138 \\
\hline C'est bon esprit & 1 Co-Founder & Donation & Paris & $15 / 06 / 15$ & 83 \\
\hline Place de la Loc & 1 Co-Founder & Rental & Paris & $11 / 06 / 15$ & 82 \\
\hline DressWing & 1 Founder & Rental & Paris & $01 / 09 / 15$ & 60 \\
\hline ShareVoisin & 1 Co-Founder & Lending & Paris & $15 / 04 / 15$ & 56 \\
\hline Mutum & 1 Co-Founder & Lending & Paris & $22 / 04 / 15$ & 101 \\
\hline Peerby & 1 Founder & Lending & Paris & $21 / 05 / 15$ & 71 \\
\hline Peuplade & 1 Director & Lending & Paris & $21 / 05 / 15$ & 41 \\
\hline Kikawa & 2 Co-Founders & Lending & Paris & $28 / 06 / 15$ & 69 \\
\hline L'Etablisienne & 1 Founder & Production & Paris & $02 / 06 / 15$ & 37 \\
\hline Ici Montreuil & 1 Co-Founder & Production & Paris & $08 / 06 / 15$ & 62 \\
\hline La Nouvelle Fabrique & 1 Director & Production & Paris & $15 / 06 / 15$ & 46 \\
\hline Mon Atelier En Ville & 1 Co-Founder & Production & Paris & $25 / 06 / 15$ & 62 \\
\hline Fablab de Rennes & 1 Co-Founder & Production & Paris & $29 / 06 / 15$ & 109 \\
\hline Volumes & 1 Co-Founder & Production & Paris & $30 / 06 / 15$ & 51 \\
\hline Electrolab & 1 Co-Founder & Production & Paris & $01 / 07 / 15$ & 114 \\
\hline Hall Couture & 1 Founder & Production & Paris & $07 / 07 / 15$ & 54 \\
\hline WoMa & 1 Co-Founder & Production & Paris & $16 / 07 / 15$ & 47 \\
\hline FacLab & 1 Founder & Production & Telephone & $13 / 08 / 15$ & 66 \\
\hline Comment Réparer & 1 Founder & Repair & Paris & $26 / 03 / 15$ & 128 \\
\hline Repair Café Coeur d'Alsace & 1 Founder & Repair & Telephone & $22 / 04 / 15$ & 61 \\
\hline Vestaire Collective & 2 Co-Founders & Resale & Paris & $15 / 04 / 15$ & 79 \\
\hline Brocante Lab & 2 Co-Founders & Resale & Paris & $04 / 05 / 15$ & 63 \\
\hline A Little Market & 1 Co-Founder and Director & Resale & Paris & $06 / 07 / 15$ & 53 \\
\hline M\&A for Ladies & 1 Co-Founder & Resale & Paris & $07 / 09 / 15$ & 58 \\
\hline The Food Assembly & 1 Co-Founder and Director & Market platform & Paris & $23 / 11 / 15$ & 90 \\
\hline
\end{tabular}

Citation: Acquier, A., Carbone, V., \& Massé, D. 2019. How to Create Value(s) in the Sharing Economy: Business Models, Scalability, and Sustainability. Technology Innovation Management Review, 9(2): 5-24. http://doi.org/10.22215/timreview/1215

Keywords: sharing economy, business model, value creation, value distribution, scalability, sustainability 


\section{Academic Affiliations and Funding Acknowledgements}
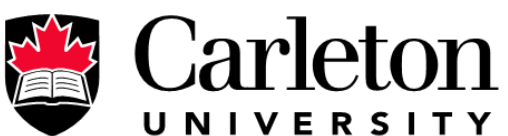

U N I V E R S I T Y

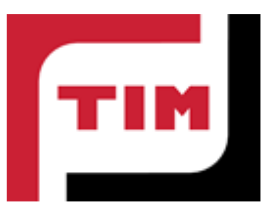

Technology Innovation Management (TIM; timprogram.ca) is an international master's level program at Carleton University in Ottawa, Canada. It leads to a Master of Applied Science (M.A.Sc.) degree, a Master of Engineering (M.Eng.) degree, or a Master of Entrepreneurship (M.Ent.) degree. The objective of this program is to train aspiring entrepreneurs on creating wealth at the early stages of company or opportunity lifecycles.

- The TIM Review is published in association with and receives partial funding from the TIM program. 